\title{
Molecular signatures of mesenchymal stem cell-derived extracellular vesicle-mediated tissue repair
}

\author{
Takeshi Katsuda and Takahiro Ochiya*
}

\begin{abstract}
Extracellular vesicles (EVs) play important roles in intercellular communications via their content molecules, and mimic, at least in part, the roles that are played by their originating cells. Consistent with this notion, an increasing number of reports have suggested that EVs derived from mesenchymal stem cells (MSCs), which are therapeutically beneficial to a wide range of diseases, can serve as drugs to treat multiple diseases. EVs contain a variety of molecules, including proteins, microRNAs, and mRNAs, and are associated with biological processes in a content molecule-dependent manner. In this article, we review the latest reports regarding the therapeutic potential of MSC-EVs by focusing on the underlying molecular mechanisms of their effects. Specifically, we feature the effects of MSC-EVs in terms of their content molecules and of the tissue recovery processes endowed by these molecules.
\end{abstract}

\section{Introduction}

Interest in extracellular vesicles (EVs), lipid-bilayered vesicles that are secreted by various types of cells, as novel carriers for drug delivery systems has increased. In a broad sense, EVs include all types of vesicles that exist in the extracellular space. In particular, 50-200 nm EVs, usually termed exosomes [1] and shedding microvesicles [2], are the primary focus for many researchers owing to their biological significance. Thus, in this article, we use the term "EV" to refer to a $50-200 \mathrm{~nm}$ vesicle. Although the functions of EVs are variable, their functions often reflect the phenotypes of their originating cells.

\footnotetext{
* Correspondence: tochiya@ncc.go.jp

Division of Molecular and Cellular Medicine, National Cancer Center Research Institute, 5-1-1 Tsukiji, Chuo-ku, Tokyo 104-0045, Japan
}

Extracellular vesicles derived from mesenchymal stem cells (MSC-EVs) have therapeutic benefits against multiple diseases [3-5]. Mesenchymal stem cells (MSCs) are stem cells that reside in adult tissues and that assist in injury recovery. These cells have thus attracted much attention as a cell source for regenerative medicine. More recently, increasing numbers of reports have indicated that MSC-EVs show therapeutic effects similar to those which can be achieved by the originating MSCs themselves. These findings imply a novel therapeutic strategy using MSC-EVs as drugs for future regenerative medicine.

In this article, we review the latest reports regarding the therapeutic potential of MSC-EVs from the point of view of their content molecules. To this end, we classify their content molecules into three groups: proteins, RNAs, and undefined molecules. The possible molecular mechanisms underlying MSC-EV-mediated therapeutic effects are discussed (Fig. 1). We also discuss the further therapeutic potential of MSC-EVs in terms of the findings obtained from comprehensive analyses of molecular components of MSC-EVs; for example, RNA sequencing and proteomic analyses of MSC-EVs.

\section{Protein-mediated therapeutic effects}

Evidence for biological functions of EV proteins was first provided by immunology studies in the late 1990s [6-10]. Thereafter, in the 2000s, the involvement of EV proteins was further described in other fields including cancer biology [11-13] and neuroscience [14-17]. Evidence for the therapeutic effects of MSC-EV proteins was not provided until after 2010 (Table 1).

MSC-EVs primarily seem to support the proliferation and apoptosis avoidance of surviving tissue cells by modulating intracellular signaling pathways. The earliest studies found that the therapeutic effect of MSC-derived paracrine factors on myocardial ischemia/reperfusion injury (MIR) is largely ascribed to EV fractions $[18,19]$. 


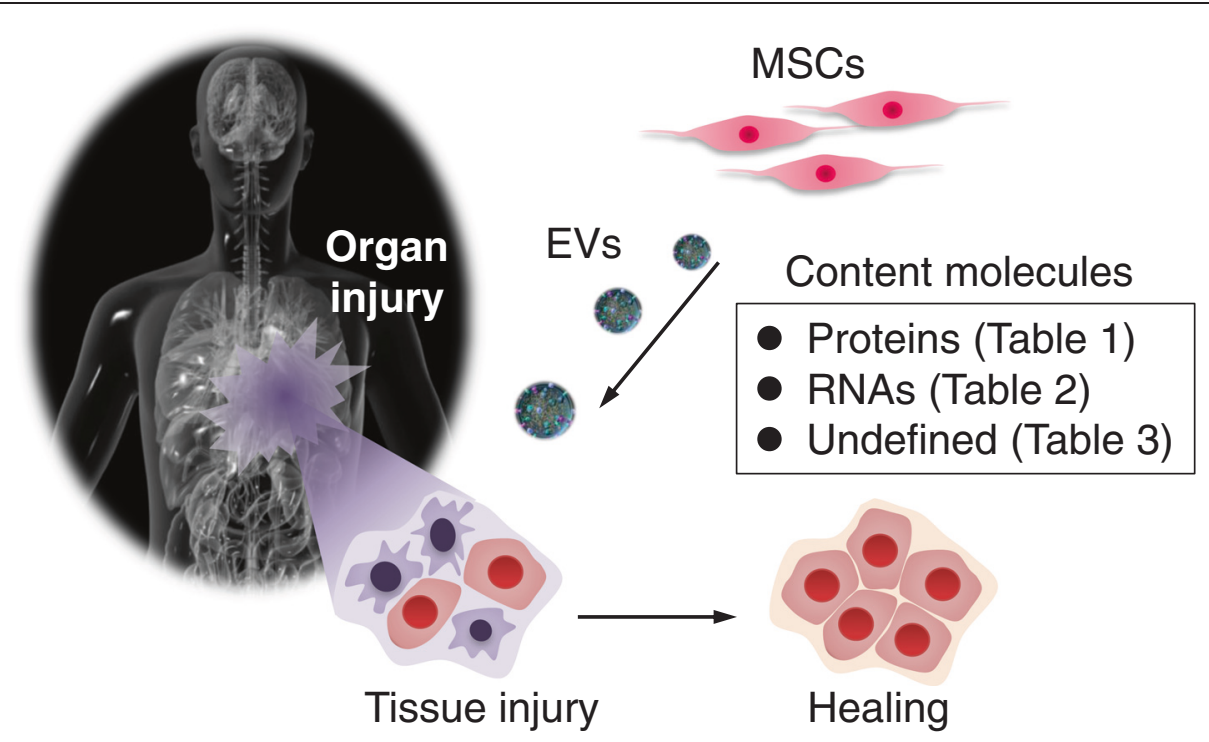

Fig. 1 Schematic representation of therapeutic effects mediated by MSC-EVS. MSC-EVs can support the recovery of injured organs, and this supportive effect is dependent on EV content molecules. In this article, content molecule-dependent therapeutic effects are classified into three categories: protein-mediated effects, RNA-mediated effects, and undefined molecule-mediated effects (summarized in Tables 1, 2 and 3, respectively). EV extracellular vesicle, MSC mesenchymal stem cell

Although the responsible EV proteins had not yet been determined specifically, the subsequent study indicated that this therapeutic effect is mediated by restoring bioenergetics as evidenced by increased ATP and NADH levels, reduced oxidative stress via reduced c-JNK phosphorylation, and promoted proliferation via PI3K/Akt pathway activation [20]. Recently, Zhang et al. [21] elegantly demonstrated that MSC-EVs promoted recovery from skin burns by promoting skin cell proliferation. This proliferative effect was due to EV-Wnt4-mediated direct promotion of $\beta$-catenin nuclear translocation.

EVs allow MSC-derived membrane enzymes with therapeutic potential to have a unique functional mode. Our group reported that adipose tissue-derived mesenchymal stem cell (ADSC)-EVs contain enzymatically active neprilysin (also known as $\mathrm{CD} 10$ ), the rate-limiting

Table 1 MSC-EV protein-mediated therapeutic effects

\begin{tabular}{|c|c|c|c|c|}
\hline $\begin{array}{l}\text { Species/MSC } \\
\text { origin }\end{array}$ & Injured organ/experimental model & $\begin{array}{l}\text { Responsible } \\
\text { protein }\end{array}$ & Possible mechanisms for the therapeutic effect & Reference \\
\hline Human/ESCs & $\begin{array}{l}\text { Heart/mouse model of MIR injury } \\
\text { (ex vivo) }\end{array}$ & ND & $\begin{array}{l}\text { Predicted to have significant biological effects on cardiac tissue } \\
\text { injury and repair, but the responsible molecules were not } \\
\text { specifically determined }\end{array}$ & {$[18]$} \\
\hline $\begin{array}{l}\text { Human/ } \\
\text { fetus }\end{array}$ & $\begin{array}{l}\text { Heart/mouse model of MIR injury } \\
\text { (ex vivo) }\end{array}$ & ND & Attenuated TGF $\beta$ signaling and reduced apoptosis & {$[19]$} \\
\hline \multirow[t]{2}{*}{ Human/ESCs } & \multirow[t]{2}{*}{ Heart/mouse model of MIR (in vivo) } & \multirow[t]{2}{*}{ ND } & $\begin{array}{l}\text { Restoration of bioenergetics, reduction of oxidative stress and } \\
\text { activation of pro-survival signaling, followed by enhancement of } \\
\text { cardiac function and geometry after MIR injury }\end{array}$ & \multirow[t]{2}{*}[20]{} \\
\hline & & & $\begin{array}{l}\text { Increased ATP and NADH, decreased oxidative stress, increased } \\
\text { phosphorylated Akt and phosphorylated GSK-3ß levels, and } \\
\text { reduced phosphorylated c-JNK levels }\end{array}$ & \\
\hline Human/UC & Skin/rat skin burn model (in vivo) & Wnt4 & $\begin{array}{l}\text { EV-carried Wnt4 promoted } \beta \text {-catenin nuclear translocation and } \\
\text { activity to enhance the proliferation and migration of skin cells }\end{array}$ & {$[21]$} \\
\hline Human/AT & $\begin{array}{l}\text { Brain/in vitro model of Alzheimer's } \\
\text { disease }\end{array}$ & Neprilysin/CD10 & $\begin{array}{l}\text { EV-mediated secretion and transfer of enzymatically active } \\
\text { neprilysin led to the degradation of intracellular and extracellular } \\
A \beta \text { in neuroblastoma cell lines }\end{array}$ & {$[22]$} \\
\hline Human/BM & $\begin{array}{l}\text { Immune system/human-into-mouse } \\
\text { xenogeneic GVHD model (in vivo) }\end{array}$ & CD73 & $\begin{array}{l}\text { Inhibition of Th1 cell effector function via EV-CD73-mediated } \\
\text { adenosine production, which activated the A2A receptor-mediated } \\
\text { adenosine pathway in the Th1 cells }\end{array}$ & {$[23]$} \\
\hline
\end{tabular}


amyloid beta $(\mathrm{A} \beta)$-degrading enzyme in the brain [22]. Coculture experiments strongly suggested that ADSCEVs were transferred to amyloid precursor proteinoverexpressing Neuro-2a cells, thereby reducing both extracellular and intracellular $A \beta$ levels. Currently, we are investigating the in vivo therapeutic potential of ADSC-EVs using animal models of Alzheimer's disease. Another report also suggested the therapeutic potential of EV-associated enzymes in graft-versus-host disease (GVHD) [23]. Bone marrow (BM)-MSC-derived EVs carry enzymatically functional CD73 (also known as ecto-5' -nucleotidase), which metabolizes AMP into adenosine, a molecule that contributes to ATP signaling. Through this signaling, A2AR-expressing T-helper type 1 (Th1) cells are led to apoptosis.

\section{RNA-mediated therapeutic effects}

One of the most attractive characteristics of EVs is their ability to transfer RNAs from one cell to another, thereby allowing the transferred RNAs to affect the recipient cells. Between 2006 and 2007, a sensational finding demonstrated that EV cargo mRNAs can be transferred and translated to proteins in recipient cells $[24,25]$. Furthermore, in 2010 EVs were shown to transfer microRNAs (miRNAs) between cells, and the transferred miRNAs displayed RNA interference (RNAi) effects in the recipient cells [26-28]. In recent years, EVcontaining RNAs have been shown to be transferred from MSCs to injured cells and to contribute to tissue recovery (Table 2).

Although more precise analyses are required, MSC-EV mRNAs are regarded as therapeutically beneficial in injured tissue recovery. The first evidence for the therapeutic effects of MSC-EVs was provided for kidney injury. Intriguingly, the therapeutic effects of MSC-EVs were partly mediated by the packaged mRNAs, which were suggested to be associated with proliferation, transcription regulation, and immunomodulation [29-31]. Another recent study demonstrated more specifically the association of the transfer of mRNA with acute lung injury (ALI) recovery [32]. EV-containing keratinocyte growth factor (KGF) mRNA was transferred from BMMSCs to alveolar epithelial type II (ATII) cells and translated to protein. This elevation of KGF protein in ATII cells, in concert with the immunomodulatory effect of MSC-EVs, led to protective effects against ALI.

miRNAs are also proposed to be key molecules that are responsible for MSC-EV-mediated therapeutic potential. miR-133b, a regulator of tyrosine hydroxylase production and a dopamine transporter, is the best characterized MSC-EV miRNA with therapeutic effects on cerebral injury. This miRNA was transferred from BMMSCs to injured neurons and then induced neurite outgrowth and promoted neural plasticity [33, 34]. Although several putative targets of miR-133b have been proposed, more detailed evidence is required to determine the critical role of MSC-EV miR-133b in the observed therapeutic effects. miR-22 in BM-MSC-EVs is reported to protect against ischemic heart disease by reducing cardiomyocyte apoptosis [35]. This anti-apoptotic effect of miR-22 was suggested to be due to direct targeting of methyl CpG binding protein 2 (mecp2), which is upregulated in the ischemic heart [36]. In addition, a similar therapeutic effect has been reported for miR-19a in BM-MSC-

Table 2 MSC-EV RNA-mediated therapeutic effects

\begin{tabular}{|c|c|c|c|c|}
\hline $\begin{array}{l}\text { Species/ } \\
\text { MSC origin }\end{array}$ & Injured organ/experimental model & $\begin{array}{l}\text { Responsible } \\
\text { RNA }\end{array}$ & Possible mechanisms for the therapeutic effect & Reference \\
\hline Human/BM & $\begin{array}{l}\text { Kidney/mouse model of AKI induced by } \\
\text { glycerol (in vivo) }\end{array}$ & $\begin{array}{l}\text { Predicted to } \\
\text { be mRNAs }\end{array}$ & Induction of proliferation of surviving intrinsic epithelial cells & {$[29]$} \\
\hline Human/BM & $\begin{array}{l}\text { Kidney/mouse model of AKI induced by } \\
\text { cisplatin (in vivo) }\end{array}$ & $\begin{array}{l}\text { Predicted to } \\
\text { be mRNAs }\end{array}$ & $\begin{array}{l}\text { Induction of survival of tubular epithelial cells via } \\
\text { anti-apoptotic effects }\end{array}$ & {$[30]$} \\
\hline Human/BM & $\begin{array}{l}\text { Kidney/rat model of AKI induced by } \\
\text { ischemia/reperfusion (in vivo) }\end{array}$ & $\begin{array}{l}\text { Predicted to } \\
\text { be mRNAs }\end{array}$ & $\begin{array}{l}\text { Proliferative and anti-apoptotic effects on surviving } \\
\text { intrinsic epithelial cells }\end{array}$ & {$[31]$} \\
\hline Human/BM & $\begin{array}{l}\text { Lung/mouse endotoxin-induced or } \\
\text { LPS-induced acute lung injury (in vivo) }\end{array}$ & KGF mRNA & $\begin{array}{l}\text { Immunosuppressive effects partly through KGF elevation, } \\
\text { which was caused by EV-mediated transfer of KGF mRNA }\end{array}$ & {$[32]$} \\
\hline Rat/BM & $\begin{array}{l}\text { Brain/rat model of middle cerebral artery } \\
\text { occlusion (in vivo) }\end{array}$ & miR-133b & Induction of neurite outgrowth of neural cells & [33] \\
\hline Rat/BM & $\begin{array}{l}\text { Brain/rat model of middle cerebral artery } \\
\text { occlusion (in vivo) }\end{array}$ & miR-133b & $\begin{array}{l}\text { Promotion of functional recovery by increasing neuroblasts } \\
\text { and induction of neurovascular plasticity by increasing vascular } \\
\text { endothelial cells }\end{array}$ & [34] \\
\hline Mouse/BM & $\begin{array}{l}\text { Heart/mouse myocardial infarction model } \\
\text { (in vivo) }\end{array}$ & $\operatorname{miR}-22$ & $\begin{array}{l}\text { Reduction of apoptosis of ischemic cardiomyocytes by directly } \\
\text { targeting methyl CpG binding protein } 2 \text { (Mecp2) via EV cargo } \\
\text { miR-22 }\end{array}$ & {$[35]$} \\
\hline Rat/BM & Heart/rat regional MIR model (in vivo) & miRNA-19a & $\begin{array}{l}\text { Reduction of the expression level of PTEN, a predicted target } \\
\text { of miR-19a, thus activating the Akt and ERK signaling pathways }\end{array}$ & {$[37]$} \\
\hline
\end{tabular}


EVs, where its target is predicted to be phosphatase and tensin homolog (PTEN) deleted from chromosome 10 [37].

\section{Molecularly undefined mechanisms of MSC-EV-mediated therapeutic effects}

Despite the rapidly increasing number of reports regarding the therapeutic effects of MSC-EVs, many lack detailed investigations identifying the molecule(s) responsible for these effects. As summarized in Table 3, the therapeutic effects of MSC-EVs include promotion of proliferation [38-42] and prevention of apoptosis $[40,42,43]$ of surviving cells, modulation of the immune system [38, 41, 44-46], suppression of fibrosis [45, 47], and promotion of angiogenesis [41, 48, 49].

Because the primary focus of this article is the molecular mechanisms underlying the therapeutic effects of MSC-EVs from the point of view of their content molecules, we do not provide a detailed review of those reports that have not elucidated the responsible molecules. Nevertheless, considering that these reports provide much insight, we will highlight some of them here. In a mouse model of allogeneic skin grafts, MSC-EVs contributed to immunosuppression by increasing the number of $\mathrm{CD}^{+} \mathrm{CD} 25^{+} \mathrm{FoxP}^{+}$regulatory $\mathrm{T}$ cells (Tregs) [46]. This immunosuppressive effect is distinct from that of MSC-EVs observed in GVHD, where MSC-EVs did

Table 3 MSC-EV-mediated therapeutic effects by undefined responsible molecules

\begin{tabular}{|c|c|c|c|}
\hline Species/MSC origin & Injured organ/experimental model & Possible mechanisms for the therapeutic effect & Reference \\
\hline Mouse/BM & Kidney/rat model of 5/6 subtotal nephrectomy (in vivo) & $\begin{array}{l}\text { Fibrosis prevention, interstitial lymphocyte infiltrates, and } \\
\text { absent tubular atrophy }\end{array}$ & {$[47]$} \\
\hline \multicolumn{4}{|l|}{ Mouse/BM } \\
\hline Human/UC & $\begin{array}{l}\text { Lung/mouse hypoxic pulmonary hypertension model } \\
\text { (in vivo) }\end{array}$ & $\begin{array}{l}\text { Suppression of the hypoxic pulmonary influx of } \\
\text { macrophages and the induction of anti-inflammatory and } \\
\text { pro-proliferative mediators }\end{array}$ & [38] \\
\hline Human/UC & Hind limb/rat ischemia model (in vivo) & $\begin{array}{l}\text { Promotion of proliferation and tubular structure formation } \\
\text { of endothelial cells in vitro and exemplified in vivo with the } \\
\text { evidence of improvement in the blood flow recovery }\end{array}$ & [48] \\
\hline Rat/BM & $\begin{array}{l}\text { Brain/rat model of middle cerebral artery occlusion } \\
\text { (in vivo) }\end{array}$ & $\begin{array}{l}\text { Enhancement of neurite remodeling, neurogenesis and } \\
\text { angiogenesis, which were evidenced by increases in axonal } \\
\text { density and synaptophysin-positive areas, and } \\
\text { doublecortin-positive neuroblast and endothelial cell } \\
\text { numbers }\end{array}$ & [39] \\
\hline Human/UC & $\begin{array}{l}\text { Kidney/rat cisplatin-induced acute kidney injury model } \\
\text { (in vivo) and in vitro culture of rat tubular epithelial } \\
\text { cells exposed to cisplatin }\end{array}$ & $\begin{array}{l}\text { Decrease in cisplatin-mediated renal oxidative stress and } \\
\text { apoptosis in vivo and increase in renal epithelial cell } \\
\text { proliferation in vitro }\end{array}$ & [43] \\
\hline Human/ESCs & $\begin{array}{l}\text { Immune system/mouse model of allogeneic skin graft } \\
\text { (in vivo) }\end{array}$ & $\begin{array}{l}\text { Induction of an attenuated proinflammatory cytokine } \\
\text { response and enhanced anti-inflammatory cytokine } \\
\text { production by monocytes, leading to polarized activation } \\
\text { of } C D 4^{+} T \text { cells to } C D 4^{+} C D 25^{+} \text {FoxP3 } 3^{+} \text {regulatory T cells } \\
\text { (Tregs) }\end{array}$ & [46] \\
\hline Human/ESCs & Liver/CCl ${ }_{4}$-induced mouse liver injury model (in vivo) & $\begin{array}{l}\text { Upregulation of the priming-phase genes during liver } \\
\text { regeneration, which subsequently led to increased } \\
\text { expression of proliferation-related proteins, PCNA } \\
\text { and cyclin } D_{1}\end{array}$ & {$[40]$} \\
\hline Horse/AT & $\begin{array}{l}\text { Vascular system/ex vivo rat aortic ring and in vitro } \\
\text { scratch assays }\end{array}$ & Mechanisms have not been identified & [49] \\
\hline Human/BM & $\begin{array}{l}\text { Lung } / \mathrm{SiO}_{2} \text {-induced mouse idiopathic pulmonary } \\
\text { fibrosis model (in vivo) }\end{array}$ & $\begin{array}{l}\text { Downregulation of inflammatory response and suppression } \\
\text { of fibrosis as evidenced by decreased collagen deposition }\end{array}$ & [45] \\
\hline Human/AT & Immune system/in vitro culture of stimulated T cells & $\begin{array}{l}\text { Inhibitory effect on the differentiation and activation of T } \\
\text { cells and reduced T cell proliferation and IFNy release in } \\
\text { in vitro stimulated cells }\end{array}$ & [44] \\
\hline Rat/BM & $\begin{array}{l}\text { Brain/rat cortical impact rat model of traumatic brain } \\
\text { injury (in vivo) }\end{array}$ & $\begin{array}{l}\text { Increased endothelial cells in the lesion boundary zone and } \\
\text { dentate gyrus, increased numbers of newly formed } \\
\text { immature and mature neurons in the dentate gyrus and } \\
\text { reduced neuroinflammation }\end{array}$ & [41] \\
\hline Mouse/AT & $\begin{array}{l}\text { Brain/in vitro culture of neuronal cells exposed to } \\
\text { oxidative stress and ex vivo cerebellar slice cultures } \\
\text { treated with lysophosphatidylcholine }\end{array}$ & $\begin{array}{l}\text { Protection of neurons from apoptotic cell death, promotion } \\
\text { of remyelination and activation of nestin-positive } \\
\text { oligodendroglial precursors }\end{array}$ & [42] \\
\hline
\end{tabular}


not affect the number of Tregs but directly decreased the numbers of Th1 cells and cytotoxic $T$ cells [23]. These two reports suggest that even phenotypically similar outputs elicited by MSC-EVs are likely to be context dependent. Thus, clarifying the difference between these two distinct immunosuppressive effects is intriguing. To this end, identifying the EV molecule(s) responsible for these effects more precisely will be important. Another interesting report suggested the surprising capacity of EVs as a transportation tool between cells. Islam et al. [50] reported that MSCs protect against ALI, and these authors ascribe this therapeutic effect to EV-mediated intercellular transfer of mitochondria. Before this report, lung epithelial cells harboring mitochondrial injury were cocultured with MSCs and were reported to receive mitochondria from MSCs, thereby recovering their proliferative capacity and lung functions [51]. Islam et al. [50] claim that this mitochondrial transfer from MSCs to lung epithelial cells is mediated by EVs; however, no direct evidence exists showing that the addition of MSCEVs to cultured epithelial cells resulted in mitochondrial transfer. In contrast, another group [32] identified mitochondrial genes in MSC-EVs, implying the involvement of mitochondrial transfer in the therapeutic outcome of MSC-EVs. Further investigation regarding this possibility is required. It should also be noted that the stress of pathophysiological conditions impacts the effects of MSC-EVs. For example, hypoxia, ischemic conditioning, or inflammatory conditioning of MSCs is shown to regulate protein or miRNA packaging into EVs and to affect their functional properties $[33,52,53]$.

\section{Future perspectives}

In the next few years, exploring and understanding more comprehensively the therapeutic effects of MSC-EVs by taking advantage of omics data will be important. Specifically, we can expect to be able to predict the beneficial characteristics of MSC-EVs. An earlier study by Kim et al. [54] performed proteome analysis of MSC-EVs and proposed several candidate signaling pathways that were expected to be activated by MSC-EVs. These predicted pathways included the Wnt, transforming growth factor beta (TGF $\beta$ ), mitogen-activated protein kinase (MAPK), peroxisome proliferator-activated receptor (PPAR), and bone morphogenetic protein (BMP) signaling pathways. Of these pathways, the MAPK and Wnt signaling pathways have been confirmed to be activated following MSC-EV administration [20, 21, 37, 40, 43]. In addition to pathway prediction, predicting a single EV molecule as a therapeutic effector will also be beneficial. Although not predicted as candidate therapeutic effectors, neprilysin/CD10 and CD73 were identified in the proteomic analyses performed by Kim et al. [54]. These two molecules were later proposed to be therapeutically valid, as already reviewed [22, 23]. Another recent study performed RNA sequencing (RNA-seq) of MSC-EVs [55]. According to this study, EVs were preferentially rich in mRNAs for transcription factors and angiogenesisassociated genes. Of these transcription factors, FoxP3 may contribute to immunosuppressive effects because FoxP3 is a master gene for Treg lineage specification. In contrast, intriguingly, RNA-seq generated reads for at least 386 annotated miRNAs but only four of these were enriched in EVs compared with the original MSCs. This finding suggests that other mechanisms may underlie the therapeutic effects of MSC-EVs. Indeed, a more recent RNA-seq study also questioned the presently wellaccepted hypothesis that miRNAs are the primary effectors of the therapeutic potential of MSC-EVs. Baglio et al. [56] performed RNA-seq to characterize the full small RNAome of MSC-EVs. Their data indicate that miRNAs and small nucleolar RNAs (snoRNAs) are significantly enriched in cells, while tRNAs and repeats form a defined pool of RNAs heavily enriched in exosomes. These authors also found that tRNA halves, which are 30-40 nucleotides long and which are produced by the cleavage of mature cytoplasmic tRNAs, appear to be massively sorted into MSC-EVs. tRNA halves have emerged as a novel class of small noncoding RNAs that might have biological functions [57]; in particular, 5' tRNA halves are suggested to serve as translation suppressors $[58,59]$. In addition, 5' tRNA halves are shown to be present in immune cell-derived EVs [60] and in body fluids such as blood [61, 62] and semen [63], suggesting their potential biological significance. In this regard, the study by Baglio et al. noted the importance of investigating not only miRNAs but also tRNAs to further explore and understand MSC-EV-mediated therapeutic effects.

Second, we would like to emphasize the possible oncogenic risks entailed by MSC-EVs. The pro-proliferative effects of MSC-EVs on injured cells imply the possibility that MSC-EVs accelerate cancer progression. At present, whether MSC-EVs have pro-cancer or anti-cancer effects remains controversial. Some studies have claimed that MSC-EVs support cancer progression [64-68], whereas others have shown the anti-tumorigenic effects of MSCEVs [69-74]. Although we do not have a reasonable explanation at present, two reports by Zhu et al. $[68,72]$ have provided insight regarding this controversy. The authors investigated the effects of MSC-EVs on two different types of cancer. While MSC-EVs attenuated the growth of bladder cancer cells [72], MSC-EVs promoted the growth and aggressiveness of renal cancer cells [68]. These contradictory observations suggest that MSC-EVs affect cancer cells in a cancer type-dependent manner. In addition, considering the notion of cancer recurrence, apparent anti-cancer effects may reflect the early stage 
of cancer cell dormancy. Indeed, some studies have suggested that anti-proliferative effects on cancer cells should be regarded as induction of cancer cell dormancy, thereby providing a platform for cancer recurrence $[75,76]$. More comprehensive insight into this controversial issue is a prerequisite for applying MSCEVs to clinical settings.

Third, we should account for an issue regarding interindividual variability in MSC-EV function. MSCs that are indistinguishable based on marker characterization could display strongly different capacities to produce cytokines and respond to inflammatory licensing [77]. Donor age and gender also affect characteristics of human MSCs, such as surface marker profiles and clonogenic capacity [78]. At present, there is no report on the inter-individual variability of MSC-EVs, and thus we should comprehensively interrogate this issue and explore criteria for clinical use of MSC-EVs. For this purpose, it will be important to know the relationship between the molecular signatures of MSC-EVs and their therapeutic efficacy, and also to know the relationship between donor MSC characteristics and the functionality of the EVs secreted by them. It might also be important to know whether there is any relationship between donor MSC characteristics and their productivity of EVs. Such information will help us to predict clinical outcomes from administration of a patient's derived MSCEVs.

\section{Conclusion}

MSC-EVs have beneficial effects on recovery from a variety of tissue injuries. These effects are mediated by MSC-EV content molecules including proteins and RNAs, and elucidation of the underlying mechanisms of these effects is now in progress. In addition, recently available omics data suggest a possibility to further explore and understand the key molecular basis of these beneficial effects of MSC-EVs. For the realization of clinical applications of MSC-EVs, however, we should be aware of the oncogenic risks that may be associated with MSC-EVs.

\section{Note}

This article is part of a thematic series on Extracellular vesicles and regenerative medicine edited by Jeffrey Karp, Kelvin $\mathrm{Ng}$ and Armand Keating. Other articles in this series can be found at http://stemcellres.com/ series/EVRM.

\section{Abbreviations}

ADSC: Adipose tissue-derived mesenchymal stem cell; ALI: Acute lung injury; ATII: Alveolar epithelial type II; A : amyloid beta; BM: Bone marrow; BMP: Bone morphogenetic protein; EV: Extracellular vesicle; GVHD: Graft-versushost disease; KGF: Keratinocyte growth factor; MAPK: Mitogen-activated protein kinase; MIR: Myocardial ischemia/reperfusion injury; miRNA: microRNA; MSC: Mesenchymal stem cell; MSC-EV: Extracellular vesicle derived from mesenchymal stem cell; PPAR: Peroxisome proliferator-activated receptor; PTEN: Phosphatase and tensin homolog; RNAi: RNA interference; RNA-seq: RNA sequencing; TGF $\beta$ : Transforming growth factor beta; Th1: T-helper type 1; Treg: Regulatory T cell.

\section{Competing interests}

The authors declare that they have no competing interests.

\section{Authors' contributions}

TO supervised the project. TK and TO wrote the manuscript. Both authors read and approved the manuscript.

\section{Acknowledgements}

This work was supported by a Grant-in-Aid for the Research Project for Practical Applications of Regenerative Medicine from Japan Agency for Medical Research and Development, AMED.

Published online: 11 November 2015

\section{References}

1. Théry C. Exosomes: secreted vesicles and intercellular communications F1000 Biol Rep. 2011;3:15.

2. Cocucci E, Racchetti G, Meldolesi J. Shedding microvesicles: artefacts no more. Trends Cell Biol. 2009;19:43-51.

3. Katsuda T, Kosaka N, Takeshita F, Ochiya T. The therapeutic potential of mesenchymal stem cell-derived extracellular vesicles. Proteomics. 2013;13:1637-53.

4. Lai RC, Chen TS, Lim SK. Mesenchymal stem cell exosome: a novel stem cell-based therapy for cardiovascular disease. Regen Med. 2011;6:481-92.

5. Biancone L, Bruno S, Deregibus MC, Tetta C, Camussi G. Therapeutic potential of mesenchymal stem cell-derived microvesicles. Nephrol Dial Transplant. 2012;27:3037-42.

6. Raposo G, Nijman HW, Stoorvogel W, Liejendekker R, Harding CV, Melief CJM, et al. B lymphocytes secrete antigen-presenting vesicles. J Exp Med. 1996;183:1161-72.

7. Théry C, Regnault A, Garin J, Wolfers J, Zitvogel L, Ricciardi-Castagnoli P, et al. Molecular characterization of dendritic cell-derived exosomes. Selective accumulation of the heat shock protein hsc73. J Cell Biol. 1999;147:599-610.

8. Zitvogel L, Regnault A, Lozier A, Wolfers J. Eradication of established murine tumors using a novel cell-free vaccine: dendritic cell derived exosomes. Nat Med. 1998;4:594-660.

9. Théry C, Ostrowski M, Segura E. Membrane vesicles as conveyors of immune responses. Nat Rev Immunol. 2009;9:581-93.

10. Bobrie A, Colombo M, Raposo G, Théry C. Exosome secretion: molecular mechanisms and roles in immune responses. Traffic. 2011;12:1659-68.

11. Wolfers J, Lozier A, Raposo G, Regnault A, Théry C, Masurier C, et al. Tumor-derived exosomes are a source of shared tumor rejection antigens for CTL cross-priming. Nat Med. 2001;7:297-303.

12. Andreola G. Induction of lymphocyte apoptosis by tumor cell secretion of fasl-bearing microvesicles. J Exp Med. 2002;195:1303-16.

13. Katsuda T, Kosaka N, Ochiya T. The roles of extracellular vesicles in cancer biology: toward the development of novel cancer biomarkers. Proteomics. 2014;14:412-25.

14. Medina M, Avila J. The role of extracellular Tau in the spreading of neurofibrillary pathology. Front Cell Neurosci. 2014;8:113.

15. Candelario KM, Steindler DA. The role of extracellular vesicles in the progression of neurodegenerative disease and cancer. Trends Mol Med. 2014;20:368-74.

16. Fevrier B, Vilette D, Archer F, Loew D, Faigle W, Vidal M, et al. Cells release prions in association with exosomes. Proc Natl Acad Sci U S A. 2004;101:9683-8.

17. Rajendran L, Honsho M, Zahn TR, Keller P, Geiger KD, Verkade P, et al. Alzheimer's disease beta-amyloid peptides are released in association with exosomes. Proc Natl Acad Sci U S A. 2006;103:11172-7.

18. Lai RC, Arslan F, Lee MM, Sze NSK, Choo A, Chen TS, et al. Exosome secreted by MSC reduces myocardial ischemia/reperfusion injury. Stem Cell Res. 2010;4:214-22.

19. Lai RC, Arslan F, Tan SS, Tan B, Choo A, Lee MM, et al. Derivation and characterization of human fetal MSCs: an alternative cell source for large-scale production of cardioprotective microparticles. J Mol Cell Cardiol. 2010;48:1215-24. 
20. Arslan F, Lai RC, Smeets MB, Akeroyd L, Choo A, Aguor ENE, et al. Mesenchymal stem cell-derived exosomes increase ATP levels, decrease oxidative stress and activate PI3K/Akt pathway to enhance myocardial viability and prevent adverse remodeling after myocardial ischemia/ reperfusion injury. Stem Cell Res. 2013;10:301-12.

21. Zhang B, Wang M, Gong A, Zhang X, Wu X, Zhu Y, et al. HucMSC-exosome mediated-Wnt4 signaling is required for cutaneous wound healing. Stem Cells. 2014;33:2158-68.

22. Katsuda T, Tsuchiya R, Kosaka N, Yoshioka Y, Takagaki K, Oki K, et al. Human adipose tissue-derived mesenchymal stem cells secrete functional neprilysin-bound exosomes. Sci Rep. 2013;3:1197.

23. Amarnath S, Foley JE, Farthing DE, Gress RE, Laurence A, Eckhaus MA, et al. Bone marrow derived mesenchymal stromal cells harness purinergenic signaling to tolerize human Th1 cells in vivo. Stem Cells. 2015;33:1200-12.

24. Valadi H, Ekström K, Bossios A, Sjöstrand M, Lee JJ, Lötvall JO. Exosomemediated transfer of mRNAs and microRNAs is a novel mechanism of genetic exchange between cells. Nat Cell Biol. 2007;9:654-9.

25. Ratajczak J, Miekus K, Kucia M, Zhang J, Reca R, Dvorak P, et al. Embryonic stem cell-derived microvesicles reprogram hematopoietic progenitors: evidence for horizontal transfer of mRNA and protein delivery. Leukemia. 2006:20:847-56

26. Pegtel DM, Cosmopoulos K, Thorley-Lawson DA, van Eijndhoven MAJ, Hopmans ES, Lindenberg JL, et al. Functional delivery of viral miRNAs via exosomes. Proc Natl Acad Sci U S A. 2010;107:6328-33.

27. Kosaka N, Iguchi H, Yoshioka Y, Takeshita F, Matsuki Y, Ochiya T. Secretory mechanisms and intercellular transfer of microRNAs in living cells. J Biol Chem. 2010;285:17442-52.

28. Zhang Y, Liu D, Chen X, Li J, Li L, Bian Z, et al. Secreted monocytic miR-150 enhances targeted endothelial cell migration. Mol Cell. 2010;39:133-44.

29. Bruno S, Grange C, Deregibus MC, Calogero RA, Saviozzi S, Collino F, et al. Mesenchymal stem cell-derived microvesicles protect against acute tubular injury. J Am Soc Nephrol. 2009;20:1053-67.

30. Bruno S, Grange C, Collino F, Deregibus MC, Cantaluppi V, Biancone L, et al. Microvesicles derived from mesenchymal stem cells enhance survival in a lethal model of acute kidney injury. PLoS One. 2012;7:e33115.

31. Gatti S, Bruno S, Deregibus MC, Sordi A, Cantaluppi V, Tetta C, et al. Microvesicles derived from human adult mesenchymal stem cells protect against ischaemia-reperfusion-induced acute and chronic kidney injury. Nephrol Dial Transplant. 2011;26:1474-83.

32. Zhu $Y$, Feng $X$, Abbott J, Fang $X$, Hao Q. Human mesenchymal stem cell microvesicles for treatment of Escherichia coli endotoxin-induced acute lung injury in mice. Stem Cells. 2014;32:116-25.

33. Xin $H$, Li Y, Buller B, Katakowski M, Zhang $Y$, Wang $X L$, et al. Exosome mediated transfer of miR-133b from multipotent mesenchymal stromal cells to neural cells contributes to neurite outgrowth. Stem Cells. 2012;30:1556-64.

34. Xin H, Li Y, Liu Z, Wang X, Shang X, Cui Y, et al. mir-133b promotes neural plasticity and functional recovery after treatment of stroke with multipotent mesenchymal stromal cells in rats via transfer of exosome-enriched extracellular particles. Stem Cells. 2013;31:2737-46.

35. Feng $Y$, Huang $W$, Wani $M, Y u X$, Ashraf $M$. Ischemic preconditioning potentiates the protective effect of stem cells through secretion of exosomes by targeting Mecp2 via miR-22. PLoS One. 2014;9:e88685.

36. Katare R, Riu F, Mitchell K, Gubernator M, Campagnolo P, Cui Y, et al. Transplantation of human pericyte progenitor cells improves the repair of infarcted heart through activation of an angiogenic program involving micro-RNA-132. Circ Res. 2011;109:894-906.

37. Yu B, Kim HW, Gong M, Wang J, Millard RW, Wang Y, et al. Exosomes secreted from GATA-4 overexpressing mesenchymal stem cells serve as a reservoir of anti-apoptotic microRNAs for cardioprotection. Int J Cardiol. 2015;182:349-60.

38. Lee C, Mitsialis SA, Aslam M, Vitali SH, Vergadi E, Konstantinou G, et al. Exosomes mediate the cytoprotective action of mesenchymal stromal cells on hypoxia-induced pulmonary hypertension. Circulation. 2012;126:2601-11.

39. Xin H, Li Y, Cui Y, Yang JJ, Zhang ZG, Chopp M. Systemic administration of exosomes released from mesenchymal stromal cells promote functional recovery and neurovascular plasticity after stroke in rats. J Cereb Blood Flow Metab. 2013;33:1711-5.

40. Tan CY, Lai RC, Wong W, Dan YY, Lim S-K, Ho HK. Mesenchymal stem cell-derived exosomes promote hepatic regeneration in drug-induced liver injury models. Stem Cell Res Ther. 2014;5:76.
41. Zhang Y, Chopp M, Meng Y, Katakowski M, Xin H, Mahmood A, et al. Effect of exosomes derived from multipluripotent mesenchymal stromal cells on functional recovery and neurovascular plasticity in rats after traumatic brain injury. J Neurosurg. 2015;122:856-67.

42. Farinazzo A, Turano E, Marconi S, Bistaffa E, Bazzoli E, Bonetti B. Murine adipose-derived mesenchymal stromal cell vesicles: in vitro clues for neuroprotective and neuroregenerative approaches. Cytotherapy. 2015;17:571-8

43. Zhou Y, Xu H, Xu W, Wang B, Wu H, Tao Y, et al. Exosomes released by human umbilical cord mesenchymal stem cells protect against cisplatin-induced renal oxidative stress and apoptosis in vivo and in vitro. Stem Cell Res Ther. 2013;4:34.

44. Blazquez R, Sanchez-Margallo FM, de la Rosa O, Dalemans W, Ãlvarez V, Tarazona R, et al. Immunomodulatory potential of human adipose mesenchymal stem cells derived exosomes on in vitro stimulated T cells. Front Immunol. 2014;5:556

45. Choi M, Ban T, Rhim T. Therapeutic use of stem cell transplantation for cell replacement or cytoprotective effect of microvesicle released from mesenchymal stem cell. Mol Cells. 2014;37:133-9.

46. Zhang B, Yin Y, Lai RC, Tan SS, Choo ABH, Lim SK. Mesenchymal stem cells secrete immunologically active exosomes. Stem Cells Dev. 2014;23:1233-44.

47. He J, Wang Y, Sun S, Yu M, Wang C, Pei X, et al. Bone marrow stem cells-derived microvesicles protect against renal injury in the mouse remnant kidney model. Nephrology (Carlton). 2012;17:493-500.

48. Zhang H-C, Liu X-B, Huang S, Bi X-Y, Wang H-X, Xie L-X, et al. Microvesicles derived from human umbilical cord mesenchymal stem cells stimulated by hypoxia promote angiogenesis both in vitro and in vivo. Stem Cells Dev. 2012;21:3289-97.

49. Pascucci L, Alessandri G, Dall'Aglio C, Mercati F, Coliolo P, Bazzucchi C, et al. Membrane vesicles mediate pro-angiogenic activity of equine adipose-derived mesenchymal stromal cells. Vet J. 2014;202:361-6.

50. Islam MN, Das SR, Emin MT, Wei M, Sun L, Westphalen K, et al. Mitochondrial transfer from bone-marrow-derived stromal cells to pulmonary alveoli protects against acute lung injury. Nat Med. 2012;18:759-65.

51. Spees JL, Olson SD, Whitney MJ, Prockop DJ. Mitochondrial transfer between cells can rescue aerobic respiration. Proc Natl Acad Sci U S A 2006;103:1283-8.

52. Salomon C, Ryan J, Sobrevia L, Kobayashi M, Ashman K, Mitchell M, et al. Exosomal signaling during hypoxia mediates microvascular endothelial cell migration and vasculogenesis. PLoS One. 2013;8:e68451.

53. Kilpinen L, Impola U, Sankkila L, Ritamo I, Aatonen M, Kilpinen S, et al. Extracellular membrane vesicles from umbilical cord blood-derived MSC protect against ischemic acute kidney injury, a feature that is lost after inflammatory conditioning. J Extracell Vesicles. 2013;2:1-15.

54. Kim H-S, Choi D-Y, Yun SJ, Choi S-M, Kang JW, Jung JW, et al. Proteomic analysis of microvesicles derived from human mesenchymal stem cells. Proteome Res. 2012;11:839-49.

55. Eirin A, Riester SM, Zhu X-Y, Tang H, Evans JM, O'Brien D, et al. MicroRNA and mRNA cargo of extracellular vesicles from porcine adipose tissue-derived mesenchymal stem cells. Gene. 2014;551:55-64.

56. Baglio SR, Rooijers K, Koppers-Lalic D, Verweij FJ, Pérez Lanzón M, Zini N, et al. Human bone marrow- and adipose-mesenchymal stem cells secrete exosomes enriched in distinctive miRNA and tRNA species. Stem Cell Res Ther. 2015;6:127.

57. Dhahbi JM. 5' tRNA halves: the next generation of immune signaling molecules. Front Immunol. 2015;6:74.

58. Yamasaki S, Ivanov P, Hu GF, Anderson P. Angiogenin cleaves tRNA and promotes stress-induced translational repression. J Cell Biol. 2009;185:35-42.

59. Ivanov P, Emara MM, Villen J, Gygi SP, Anderson P. Angiogenin-induced tRNA fragments inhibit translation initiation. Mol Cell. 2011;43:613-23.

60. Nolte-'t Hoen EN, Buermans HP, Waasdorp M, Stoorvogel W, Wauben MH. 't Hoen PA. Deep sequencing of RNA from immune cell-derived vesicles uncovers the selective incorporation of small non-coding RNA biotypes with potential regulatory functions. Nucleic Acids Res. 2012;40:9272-85.

61. Dhahbi JM, Spindler SR, Atamna H, Boffelli D, Martin DI. Deep sequencing of serum small RNAs identifies patterns of 5' tRNA half and YRNA fragment expression associated with breast cancer. Biomark Cancer. 2014;6:37-47.

62. Meiri E, Levy A, Benjamin H, Ben-David M, Cohen L, Dov A, et al. Discovery of microRNAs and other small RNAs in solid tumors. Nucleic Acids Res. 2010;38:6234-46. 
63. Vojtech L, Woo S, Hughes S, Levy C, Ballweber L, Sauteraud RP, et al. Exosomes in human semen carry a distinctive repertoire of small non-coding RNAs with potential regulatory functions. Nucleic Acids Res. 2014; $42: 7290-304$

64. Zhu W, Huang L, Li Y, Zhang X, Gu J, Yan Y, et al. Exosomes derived from human bone marrow mesenchymal stem cells promote tumor growth in vivo. Cancer Lett. 2012;315:28-37.

65. Munoz JL, Bliss SA, Greco SJ, Ramkissoon SH, Ligon KL, Rameshwar P. Delivery of functional anti-miR-9 by mesenchymal stem cell-derived exosomes to glioblastoma multiforme cells conferred chemosensitivity. Mol Ther Nucleic Acids. 2013;2:e126.

66. Roccaro A, Sacco A, Maiso P. BM mesenchymal stromal cell-derived exosomes facilitate multiple myeloma progression. J Clin Invest. 2013;123:1542-55.

67. Lin R, Wang S, Zhao RC. Exosomes from human adipose-derived mesenchymal stem cells promote migration through Wnt signaling pathway in a breast cancer cell model. Mol Cell Biochem. 2013;383:13-20.

68. Du T, Ju G, Wu S, Cheng Z, Cheng J, Zou X, et al. Microvesicles derived from human Wharton's jelly mesenchymal stem cells promote human renal cancer cell growth and aggressiveness through induction of hepatocyte growth factor. PLoS One. 2014;9:e96836.

69. Fonsato V, Collino F, Herrera MB, Cavallari C, Deregibus MC, Cisterna B, et al. Human liver stem cell-derived microvesicles inhibit hepatoma growth in SCID mice by delivering antitumor microRNAs. Stem Cells. 2012;30:1985-98.

70. Bruno S, Collino F, Deregibus MC, Grange C, Tetta C, Camussi G. Microvesicles derived from human bone marrow mesenchymal stem cells inhibit tumor growth. Stem Cells Dev. 2012;22:758-71.

71. Lee H, Finniss S, Cazacu S, Bucris E. Mesenchymal stem cells deliver synthetic microRNA mimics to glioma cells and glioma stem cells and inhibit their cell migration and self-renewal. Oncotarget. 2013:4:346-61.

72. Wu S, Ju GQ, Du T, Zhu YJ, Liu GH. Microvesicles derived from human umbilical cord Wharton's jelly mesenchymal stem cells attenuate bladder tumor cell growth in vitro and in vivo. PLoS One. 2013;8:e61366.

73. Katakowski M, Buller B, Zheng X, Lu Y, Rogers T, Osobamiro O, et al. Exosomes from marrow stromal cells expressing miR-146b inhibit glioma growth. Cancer Lett. 2013;335:201-4.

74. Lee J-K, Park S-R, Jung B-K, Jeon $Y-K$, Lee $Y-S$, Kim M-K, et al. Exosomes derived from mesenchymal stem cells suppress angiogenesis by down-regulating VEGF expression in breast cancer cells. PLoS One. 2013;8:e84256.

75. Lim PK, Bliss SA, Patel SA, Taborga M, Dave MA, Gregory LA, et al. Gap junction-mediated import of microRNA from bone marrow stromal cells can elicit cell cycle quiescence in breast cancer cells. Cancer Res. 2011;71:1550-60.

76. Ono M, Kosaka N, Tominaga N, Yoshioka Y, Takeshita F, Takahashi R-U, et al. Exosomes from bone marrow mesenchymal stem cells contain a microRNA that promotes dormancy in metastatic breast cancer cells. Sci Signal. 2014;7:ra63.

77. Ménard C, Tarte K. Immunoregulatory properties of clinical grade mesenchymal stromal cells: evidence, uncertainties, and clinical application. Stem Cell Res Ther. 2013;4:64.

78. Siegel G, Kluba T, Hermanutz-Klein U, Bieback K, Northoff H, Schäfer R. Phenotype, donor age and gender affect function of human bone marrow-derived mesenchymal stromal cells. BMC Med. 2013;11:146 